\title{
Research on the Environmental Accounting Information Disclosure of China's Petroleum Industry
}

\author{
Ang Li \\ Department of Economics and Management, North China Electric Power University, Baoding City, \\ China \\ Email: 1074528904@qq.com
}

Keywords: Environmental accounting information disclosure; Petroleum industry; Countermeasure and suggestion.

\begin{abstract}
This paper analyzes the environmental accounting information of 14 listed companies in petroleum industry, and summarizes the problems which exist in the disclosure of environmental accounting information in our country. Finally, combined with foreign advanced experience, the paper gives recommendations, such as refining laws and regulations, formulate specific environmental accounting standard, strengthen the internal control system-building of enterprise, enhance audit from dependent third-party and increase the propaganda of environmental protection knowledge. Hope it to be useful for China's improvement and development of environmental accounting information disclosure system.
\end{abstract}

\section{Introduction}

China has made remarkable achievements in the field of modernization, but environmental problems have constrained the development of the national economy. According to statistics, 80\% of pollution comes from production and business activities of enterprises (Meng Lee, 1999)

Therefore, the problem of development of enterprise environmental accounting has been more and more urgent, and the relevant disclosure of the environmental accounting information became prerequisite to the stakeholders. The disclosure of the environmental accounting isn't only the need of macro-economy management, but also the need of the company's internal management, as a main form of stakeholders, such as government, the environmental protection department and investors, reporting the protection of the ecological environment and other social responsibility situation.

At present, the development of the theory and practice about the disclosure of environmental accounting information is rapid, even more rapid and mature in western developed countries. There are some famous and significant research achievement, for example, "Environmental Debt Accounting” of Financial Accounting Standards Board, "Environmental Performance Report” of Charter Accountants of Canada and "Guide of Environmental Accounting” of Environment Agency of Japan. Meanwhile, China started research rather late on environmental accounting, has advanced in leaps in recent years. November 16, 2011. The United Nations Environment Programme published a green economy comprehensive report “Towards a Green Economy-Various Ways of the Realization of Sustainable Development and Eliminating Poverty” for the first time in Beijing.

However, it is only an emerging discipline in China, and much improvement is to be made. Given these, this paper was written centering around the environmental accounting information disclosure with a detailed study on severely polluted oil industry.

\section{Analyzing the Current Situation of the Disclosure of Oil Industry, Taking 14 Listing Corporation of Oil Industry as Samples}

The oil industry is one of the most important pillar industries of the world economy, including petroleum processing, cooking, and oil and gas production. Due to the particularity of oil industry, oil companies may cause pollution in each step of operation. The passage takes listing corporation of oil industry in Shanghai and Shenzhen as the object of study, collects environmental statement, 
social responsibility report and sustainable development report in 2009,2010,2011 of 14 listing corporation and does the investigation and statistics on the disclosure of the environmental accounting information. The data is collected form Sina Financial Network, the huge influx of information network and the company's official website.

Table 1 The list of 14 listed companies in petroleum industry

\begin{tabular}{|c|c|c|c|c|c|}
\hline Company & Exchange & Stock code & Company & Exchange & Stock code \\
\hline SINOPEC & $\begin{array}{l}\text { Shanghai } \\
\text { stock } \\
\text { exchange }\end{array}$ & 600028 & GUANGJU & $\begin{array}{l}\text { Shenzhen } \\
\text { stock } \\
\text { exchange }\end{array}$ & 000096 \\
\hline HAIYUE & $\begin{array}{l}\text { Shanghai } \\
\text { stock } \\
\text { exchange }\end{array}$ & 600387 & INTERNATIONGAL & $\begin{array}{l}\text { Shenzhen } \\
\text { stock } \\
\text { exchange }\end{array}$ & 000159 \\
\hline COOEC & $\begin{array}{l}\text { Shanghai } \\
\text { stock } \\
\text { exchange }\end{array}$ & 600583 & TAISHAN & $\begin{array}{l}\text { Shenzhen } \\
\text { stock } \\
\text { exchange }\end{array}$ & 000554 \\
\hline $\begin{array}{l}\text { SINOPEC } \\
\text { SHANGHAI }\end{array}$ & $\begin{array}{l}\text { Shanghai } \\
\text { stock } \\
\text { exchange }\end{array}$ & 600688 & MAOMING & $\begin{array}{l}\text { Shenzhen } \\
\text { stock } \\
\text { exchange }\end{array}$ & 000637 \\
\hline CNOOC & $\begin{array}{l}\text { Shanghai } \\
\text { stock } \\
\text { exchange }\end{array}$ & 601808 & XINGCHANG & $\begin{array}{l}\text { Shenzhen } \\
\text { stock } \\
\text { exchange }\end{array}$ & 000819 \\
\hline CNPC & $\begin{array}{l}\text { Shanghai } \\
\text { stock } \\
\text { exchange }\end{array}$ & 601857 & ZHUNDONG & $\begin{array}{l}\text { Shenzhen } \\
\text { stock } \\
\text { exchange }\end{array}$ & 002207 \\
\hline LIAOTONG & $\begin{array}{l}\text { Shenzhen } \\
\text { stock } \\
\text { exchange }\end{array}$ & 000059 & ORIENTAL & $\begin{array}{l}\text { Shenzhen } \\
\text { stock } \\
\text { exchange }\end{array}$ & 002221 \\
\hline
\end{tabular}

Data source: Sina finance and economics network

Table 2 Environmental accounting information disclosure method of the listed companies in petroleum industry

\begin{tabular}{|c|c|c|c|c|c|c|}
\hline & \multicolumn{2}{|c|}{2009} & \multicolumn{2}{c|}{2010} & \multicolumn{2}{c|}{2011} \\
\hline & Quantity & Proportion & Quantity & Proportion & Quantity & Proportion \\
\hline $\begin{array}{c}\text { director's } \\
\text { report }\end{array}$ & 7 & $50.00 \%$ & 8 & $57.14 \%$ & 10 & $71.43 \%$ \\
\hline $\begin{array}{c}\text { Report of } \\
\text { supervisory } \\
\text { committee }\end{array}$ & - & - & 1 & $7.14 \%$ & 1 & $7.14 \%$ \\
\hline $\begin{array}{c}\text { Notes to } \\
\text { financial } \\
\text { statement }\end{array}$ & 5 & $35.71 \%$ & 5 & $35.71 \%$ & 6 & $42.86 \%$ \\
\hline $\begin{array}{c}\text { Important } \\
\text { item }\end{array}$ & - & - & 2 & $14.29 \%$ & 1 & $7.14 \%$ \\
\hline $\begin{array}{c}\text { Independent } \\
\text { report }\end{array}$ & 7 & $50.00 \%$ & 7 & $50.00 \%$ & 7 & $50.00 \%$ \\
\hline Other & 3 & $21.43 \%$ & 4 & $28.57 \%$ & 4 & $28.57 \%$ \\
\hline
\end{tabular}

From table 2 we can found that, most of listed companies in petroleum industry adopt mixed way of disclosure. Most companies choose to disclose on the director's report or notes to financial statements. 
Table 3 Environmental accounting information disclosure content of the listed companies in petroleum industry

\begin{tabular}{|c|c|c|c|c|c|c|}
\hline & \multicolumn{2}{|c|}{2009} & \multicolumn{2}{c|}{2010} & \multicolumn{2}{c|}{2011} \\
\hline & Quantity & Proportion & Quantity & Proportion & Quantity & Proportion \\
\hline Policy impact & 5 & $35.71 \%$ & 6 & $42.86 \%$ & 7 & $50.00 \%$ \\
\hline Anti-pollution measure & 8 & $57.14 \%$ & 7 & $50.00 \%$ & 9 & $64.29 \%$ \\
\hline $\begin{array}{c}\text { Environment } \\
\text { Management System } \\
\text { Certification }\end{array}$ & 8 & $57.14 \%$ & 8 & $57.14 \%$ & 8 & $57.14 \%$ \\
\hline Environmental inputs & 4 & $28.57 \%$ & 6 & $42.86 \%$ & 4 & $28.57 \%$ \\
\hline $\begin{array}{c}\text { Environmental damage } \\
\text { costs }\end{array}$ & 0 & $0.00 \%$ & 0 & $0.00 \%$ & 0 & $0.00 \%$ \\
\hline $\begin{array}{c}\text { Environmental } \\
\text { protection grants and } \\
\text { subsidies }\end{array}$ & 2 & $14.29 \%$ & 2 & $14.29 \%$ & 4 & $28.57 \%$ \\
\hline Environmental rewards & 5 & $35.71 \%$ & 6 & $42.86 \%$ & 5 & $35.71 \%$ \\
\hline $\begin{array}{c}\text { Environmental } \\
\text { improved }\end{array}$ & 8 & $57.14 \%$ & 8 & $57.14 \%$ & 9 & $64.29 \%$ \\
\hline Environmental audit & 0 & $0.00 \%$ & 0 & $0.00 \%$ & 0 & $0.00 \%$ \\
\hline Other & 0 & $0.00 \%$ & 2 & $14.29 \%$ & 2 & $14.29 \%$ \\
\hline
\end{tabular}

From table 3, in nearly three years, disclosure content of these listed companies changed little and was relatively concentrated, which seemed overall stable. Environmental accounting information disclosure by companies usually includes Anti-pollution measures, Environmental Management System Certification and Environmental improved. Policy impact and Environmental rewards are included too. However, Environmental damage costs and Environmental audit are less or even not mentioned.

Table 4 Environmental accounting information disclosure form of the listed companies in petroleum industry

Note: A represents qualitative form, B represents quantitative form, C represents the combination of

\begin{tabular}{|c|c|c|c|c|c|c|c|c|c|c|}
\hline & \multicolumn{3}{|c|}{2009} & \multicolumn{3}{|c|}{2010} & \multicolumn{3}{c|}{2011} \\
\hline & A & B & C & A & B & C & A & B & C \\
\hline Policy impact & 5 & - & - & 6 & - & - & 7 & - & - \\
\hline Anti-pollution measures & 8 & - & - & 7 & - & - & 9 & - & - \\
\hline Environmental Management System Certification & 8 & - & - & 8 & - & - & 8 & - & - \\
\hline Environmental inputs & - & 2 & 2 & 1 & 2 & 3 & - & 2 & 2 \\
\hline Environmental damage costs & - & - & - & - & - & - & - & - & - \\
\hline Environmental protection grants and subsidies & 1 & 1 & - & 1 & 1 & - & 2 & 2 & - \\
\hline Environmental rewards & 4 & - & 1 & 5 & - & 1 & 4 & - & 1 \\
\hline Environmental improved & 3 & 3 & 2 & 4 & 1 & 3 & 5 & 1 & 3 \\
\hline Environmental audit & - & - & - & - & - & - & - & - & - \\
\hline Other & - & - & - & 2 & - & - & 2 & - & - \\
\hline Total & 29 & 6 & 5 & 34 & 4 & 7 & 37 & 5 & 6 \\
\hline
\end{tabular}

qualitative and quantitative forms.

From table 4 we can see that, qualitative form accounts for most and is far higher than the other two forms, especially like Policy impact, Anti-pollution measures and Environmental Management System Certification, which are difficult to be described in qualitative way.

Summary of Current Situation of Environmental Accounting Information Disclosure in Petroleum Industry

Mandatory is strong, while autonomy is poor. From the point of enterprise environmental 
information disclosure motivation, most companies are subject to restrictive regulations. They short of initiative and creativity, not realizing the disclosure has an important positive role to the enterprise itself.

Qualitative information is more while quantitative information is less. Although the disclosure is abundant with illustrations and pictures, qualitative form accounts for most and quantitative information is less. The report lacks hard data, resulting poor reliability and comparability.

There's more positive information whereas there is less negative information. When it comes to relative reward-penalty situation, most companies adequately disclose the reward, but rarely mention punishment of breaking environmental laws or other loss.

Disclosure content is disorganized, and report pattern is not uniformed. The unified disclosure methods cause it more inconvenient for information demander to consult the environmental accounting information, difficult to gather information. Then, the report user can hardly see the full picture of the environmental accounting information of enterprises. In addition, non-uniform items cause poor comparability between companies.

The information lacks reliability and validity. All companies are short of information audit. Without independent check of the social responsibility report, disclosed information has poor reliability and limited use value for stakeholders.

\section{Countermeasures Aiming at Improving Environmental Accounting Information Disclosure}

Refine laws and regulations, lightening up law enforcement. For the laws and regulations our country published to protect environment, although there are main requirements and corresponding punishment in the gross, many requirements of details is fuzzy, giving some enterprises chances to go through their legal loopholes.

Insist "Voluntary, supplemented by mandatory" principle. Our government should publish the corresponding incentive policy. They should implement preferential tax and fiscal subsidies for environmental protection companies and impose a fine to polluting enterprises, to mobilize the enthusiasm and initiative of disclosing environmental information.

Formulate specific environmental accounting standard to rule environmental accounting information disclosure. It is necessary to set up the accounting method and disclosure method, combining physical truth of China, especially accounting elements, way of recognition and measurement, disclosure content and form, to unify the operation of environmental accounting, so that the disclosed information would be more reliable.

Strengthen the internal control system-building of enterprise. Companies should set up and perfect the internal audit department, regularly review the accounting matters and incorporate environmental benefit into the internal performance assessment program.

Enhance audit from dependent third-party, and emphasize supervise on quality of disclosure. Environmental accounting objectively require audit from third-party too, as financial accounting. Medium institutions should be progressive, studying and mastering audit skill of environmental accounting information, to provide effective supervise on petroleum enterprise.

Increase the propaganda of environmental protection knowledge. Each aspect of community, including general public, news media and environmental organizations, should enhance the popularization of science for oil to improve the environmental protection consciousness, utilize public voice to press companies to disclose environmental accounting information.

\section{Summary}

This paper describes what the environmental accounting information disclosure is in China's petroleum industry; accordingly, suggesting improving it from method, content and form. Hope it can give useful reference to other industries. 


\section{References}

[1]Hong Xu: Research on Theory and Practice of Environment Accounting. China People's University Press (1998)

[2]Gray.R: Accounting for the Environment. Paul Chapman Publishing. London (2001)

[3] Shufang Xiao, Wei Hu: Building of Chinese Enterprises’ Environmental Information Disclosure System, Journal of Accounting Research (2005), 47-52

[4] Patten D.M: Intra-industry Environmental Disclosure in Response to the Alaskan Oil Spill: Anode on Legitimacy Theory. Accounting, Organization and Society (1992), 471-475

[5]FASB. Emission Allowance Board Meeting Handout. (2007)

[6]Disclosure Hypothesis Using 1991 Annual Report Data [J].The international Journal of Accounting (1996), 2:127-136

[7]Stephanie stray: Corporate Environmental Reporting and Disclosure: Where to Look and What You Get. Environment Research Journal. (2011), 463-483

[8]Xiao Xu:Study on Environmental Theory and Practice. CITIC Publishing House (2007)

[9]Xiaomei Guo, Huasheng Hong: Nature of Environmental Information Disclosure. China Finance Newspaper (2001), 02

[10]Jianxin Geng, Ruojing Jiao: Research on Listed Companies Environmental Information Disclosure, Journal of Accounting Research (2002), 46-49 